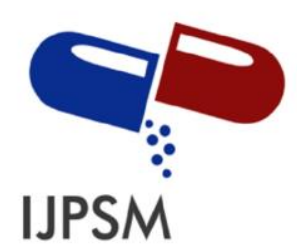

Vika Ramadhani et al, International Journal of Pharmaceutical Sciences and Medicine (IJPSM),

Vol.6 Issue. 7, July- 2021, pg. 25-39

ISSN: 2519-9889

Impact Factor: 3.426

\title{
Overview of Phytochemicals and Pharmacological Activity of Keji Beling Plant (Strobilanthes crispus Bl.)
}

\author{
Vika Ramadhani $^{1}$; Rusdi $^{1}$; Zikra Azizah ${ }^{1}$; Harrizul Rivai ${ }^{2 *}$ \\ ${ }^{1}$ College of Pharmacy (STIFARM), Jl. Raya Siteba Kurao Pagang, Padang 25147, Indonesia \\ ${ }^{2}$ Faculty of Pharmacy, Andalas University, Limau Manih Campus, Padang 25163, Indonesia \\ "Email: harrizul@yahoo.co.id; harrizul@phar.unand.ac.id
}

DOI: 10.47760/ijpsm.2021.v06i07.003

\begin{abstract}
Nowadays, traditional medicine in the form of medicinal plants or herbs is widely used by the community. Treatment with plants that exist in nature and having relatively minor side effects can also be used for an extended period. The purpose of this review article is to seek information on the phytochemical content and pharmacological activity of keji beling plants (Strobilanthes crispus Bl.). This information was searched through the Google Scholar search engine in the last eleven years $(2010$ - 2021). The results of this information show that vile beling has a chemical content in the form of potassium, sodium, silicate acid, alkaloids, carbohydrates, phenolic, tannins, saponins, flavonoids, polyphenols, terpenoids, and steroids. Pharmacologically keji beling plants have antiurolithic, antidiabetic, antioxidant, antibacterial, anti-inflammatory, antiobesity, wound healing, anticancer, cytotoxic, and peptic ulcer effects. Thus, it can be concluded that the keji beling plant is one of the plants rich in phytochemical compounds scattered on the stems and leaves. In addition, this plant has benefits for treating a wide variety of diseases. Therefore, keji beling can be developed into potential plants as an herb for various conditions, especially stone urination and antidiabetic.
\end{abstract}

Keywords: Keji beling (Strobilanthes crispus B1.), phytochemicals, pharmacological activity.

\section{Introduction}

Keji beling (Strobilanthes crispus) is locally known as "spinach coral," "broken glass," "jin stone," and "broken beling" in Malaysia. This plant has traditionally been used to improve endurance, treat kidney stones, treat diabetes mellitus, high blood treatment, and wound treatment [1].

Keji beling plant is a herbal medicinal plant that comes from Madagascar to Indonesia. The plant contains high content of minerals and vitamins $\mathrm{C}, \mathrm{B} 1$, andB2. Keji beling plants have phytochemical compounds such as polyphenols, flavonoids, catechins, alkaloids, caffeine, and tannins. Pharmacological typology shows that keji beling plants have antioxidant activity, free radical exterminator, anticancer, antidiabetic, antimicrobial, wound healing, and antiulcerogenic [2].

The name of the area is keji beling is daun picah beling, enyoh kelo, keci beling (Java). Part used as a folk remedy is the leaf. The benefit is as a stone urine remedy. The standard dosage is 2 x 15 leaves/day. How to make/use is: boil the leaves with two glasses of water, filter, drink while warm [3]. 


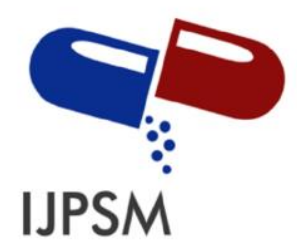

Vika Ramadhani et al, International Journal of Pharmaceutical Sciences and Medicine (IJPSM), Vol.6 Issue. 7, July- 2021, pg. 25-39

The pharmacological effect of keji beling leaves can dissolve calcium salts and magnesium kidney stones. Treatable diseases are tumors, diabetes mellitus, jaundice, piles, high cholesterol, and ulcers. Its use empirically eats three pieces of fresh leaves daily as fresh vegetables [4].

\subsection{Classification of keji beling plants [5]}

Synonym: Sericocalyx crispus L

Division: Spermatophyta

Subdivision: Angiospermae

Class: Dicotyledonae

Nation: Solanales

Family: Acanthaceae

Marga: Strobilanthes

Type: Strobilanthes crispus B1.

Common Name: Keji Beling

\subsection{Morphology of keji beling plants}

Keji beling grows wild in forests, riversides, cliffs and is often planted as fence plants in yards or parks. This plant is found from Madagascar to Indonesia, which grows at an altitude of $50 \mathrm{~m}$ to $1,200 \mathrm{~m}$ above sea level. This shrub has a height of $0.5-1 \mathrm{~m}$. Stems are segmented, round, branched, rough-haired, and green in color. Branches that touch the soil will disco the roots to be separated from the parent plant (Figure 1). Single leaves are short-stemmed, with a facing position. Strands of lanset leave elongated or almost ellipse, jagged or bitten edges, tapered ends, pointy base, both rough surfaces, pinnate reflection, length 9-18 cm, width $3-6 \mathrm{~cm}$, and green (Figure 2). Compound inflorescences are gathered in solid threads. The flower crown is divided into five funnel-shaped petals, $1.5-2 \mathrm{~cm}$ long, haired, and yellow. Fruit is bobbin-shaped, containing 2-4 seeds. The seeds are round, flattened small, brown. Propagation of plants with roots, cuttings, stems, or branches is quite old (Figure 3) [6].

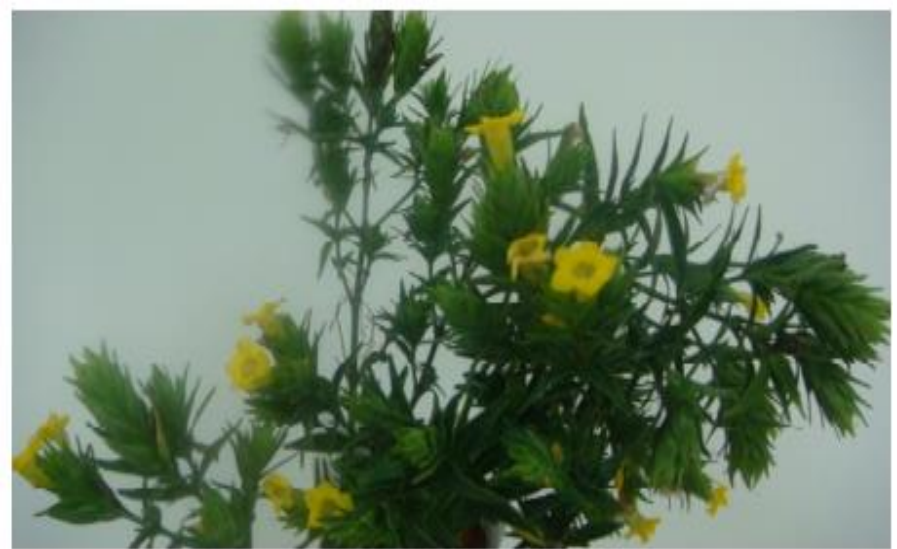

Figure 1: Leaves, stems, and flowers of keji beling plants (Strobilanthes crispus B1.) [2] 


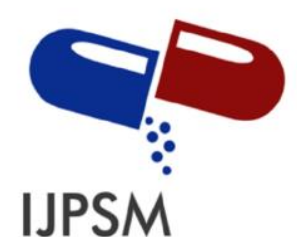

Vika Ramadhani et al, International Journal of Pharmaceutical Sciences and Medicine (IJPSM),

Vol.6 Issue. 7, July- 2021, pg. 25-39

ISSN: 2519-9889

Impact Factor: 3.426

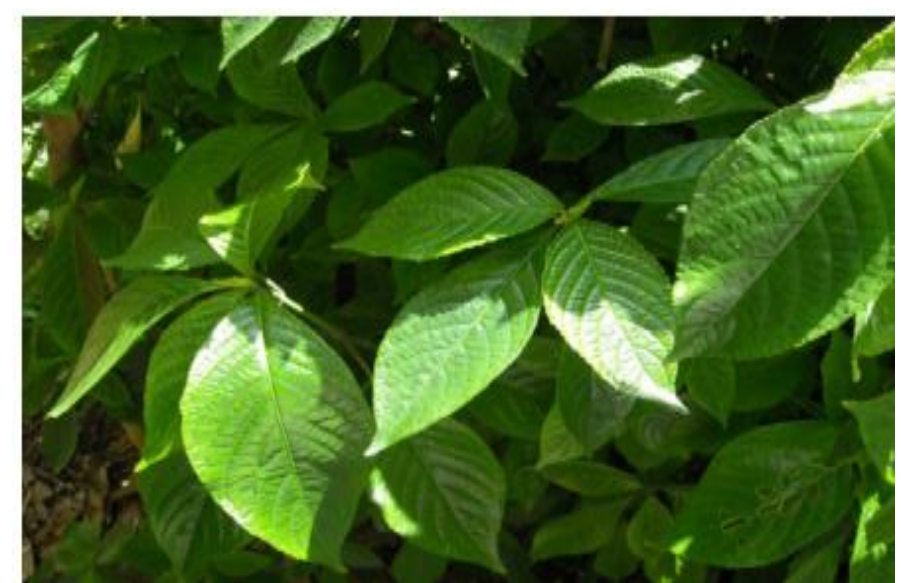

Figure 2: Leaves of keji beling plants (Strobilanthes crispus B1.) [2]

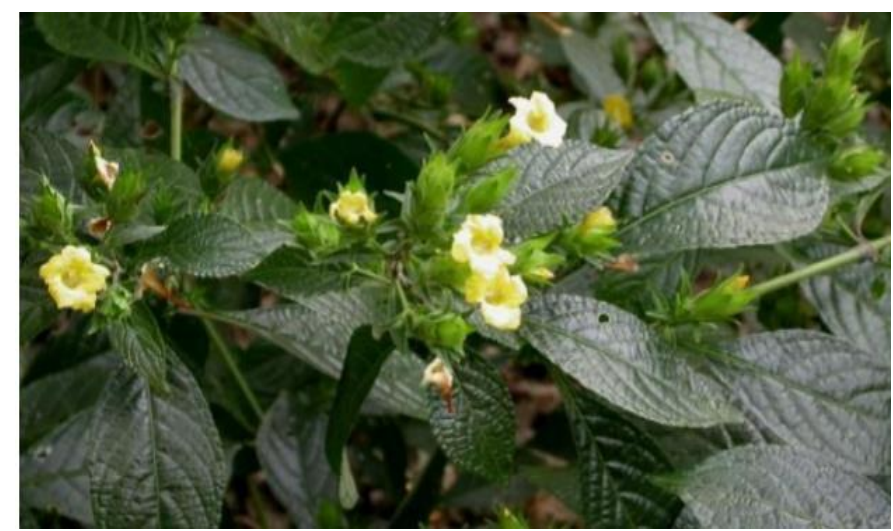

Figure 3: Leaves and flowers of keji beling plants (Strobilanthes crispus Bl.) [4]

Keji beling leaves (Strobilanthes crispus B1.) contain saponins, flavonoids, glycosides, sterols, terpene, fat, and mineral groups (high levels of potassium, silicate acid, sodium, calcium). Potassium is a strong diuretic and can dissolve stones formed from calcium oxalate and calcium carbonate salts in the bile, bladder, and kidney content. Silicate acid can stimulate the stomach so that people with gastric pain (gastritis) can not drink a decoction of this medicinal plant [6].

\section{Data collection}

In compiling this review article, the technique used is to use the method of study of libraries in the form of official books, national and international journals published in the last eleven years (2010 - 2021). In making a review of this article, we used a search of data on online media with the keyword "Strobilanthes crispus Bl." The primary reference searches in this review are conducted through trusted web such as Google Scholar, ResearchGate, NCBI, and other trusted journal databases. 


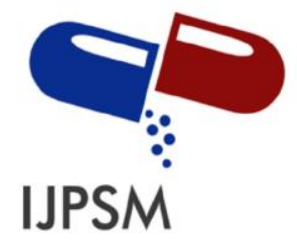

Vika Ramadhani et al, International Journal of Pharmaceutical Sciences and Medicine (IJPSM), Vol.6 Issue. 7, July- 2021, pg. 25-39

ISSN: 2519-9889

Impact Factor: 3.426

\section{Phytochemical Review}

The content of phytochemistry contained in the keji beling plants is summarized in Table 1 below.

Table 1: Phytochemical content of leaves and stems of keji beling (Strobilanthes crispus B1.)

\begin{tabular}{|l|l|l|l|l|l|}
\hline No & Plant parts used & $\begin{array}{l}\text { Extraction } \\
\text { method }\end{array}$ & Solvent & Compounds contained & Ref. \\
\hline 1. & leaf & Maceration & N - Hexane & Alkaloids, Tannins & {$[7]$} \\
\hline 2. & leaf & Maceration & methanol & $\begin{array}{l}\text { Steroids, Terpenoids, Tannins, } \\
\text { Saponins }\end{array}$ & {$[7]$} \\
\hline 3. & leaf & Maceration & Ethyl-Acetate & Alkaloid, steroid, terpenoid & {$[7]$} \\
\hline 4. & trunk & Maceration & methanol & Alkaloid & {$[8]$} \\
\hline 5. & Leaves and Stems & Maceration & methanol & Carbohydrates & {$[8]$} \\
\hline 6. & Leaves and Stems & Maceration & methanol & Phytosterols & {$[8]$} \\
\hline 7. & Leaves and Stems & Maceration & methanol & Terpenoid & {$[8]$} \\
\hline 8. & Leaves and Stems & Maceration & methanol & Phenolic & {$[8]$} \\
\hline 9. & trunk & Maceration & methanol & Flavonoid & {$[8]$} \\
\hline 10. & leaf & Superkritis & $\begin{array}{l}\text { Supercritical carbon } \\
\text { dioxide + ethanol }\end{array}$ & $\begin{array}{l}\text { Catechin, epicatechin, rutin, } \\
\text { myricetin, luteolin, apigenin, } \\
\text { naringenin, kaempferol }\end{array}$ & {$[9]$} \\
\hline
\end{tabular}

Phytochemical screening of the keji beling plant revealed alkaloids, steroids, terpenoids, tannins, and saponins in all extracted samples. Phytochemical compounds detected in each extract are summarized in Table 1 above [7].

Species of Strobilanthes of both leaves and stems indicate terpenoids, flavonoids, phytosterols, phenolic compounds, fatty oils, and carbohydrates. Terpenoids and phytosterols are also present in all species of Strobilanthes. On the other hand, phenolics, carbohydrates, flavonoids are found in most species of Strobilanthes. In addition, alkaloids, glycosides, saponins, proteins, fatty oils are found in some species of Strobilanthes. Among the species studied are S. integrifolius, S. ixiocephalus, S. reticulatus var. reticulatus, Strobilanthes Blume sp. and the leaves of S. lupulinus, S. barbatus indicate the absence of alkaloids. Glycosides are found only in S. ciliatus (leaves), S. callosus (stems), and S. heyneanus (branches). Saponins are found in S. ciliatus (leaves), S. ixiocephalus (leaves, stems), S. callosus (leaves), and the leaves and stems of $S$. heyneanus. Proteins are found only in the branches of S. callosus and S. sessilis var. Ritchie. Fat oil is also known as a yellow carrier oil found in the species Strobilanthes.

The bioactive flavonoid compound Strobilanthes crispus leaves (Broken Glass) obtained using supercritical extraction of carbon dioxide $\left(\mathrm{SC}-\mathrm{CO}_{2}\right.$ ) has been investigated, and rough extract results obtained compared to each other to choose the best operating parameters. Because carbon dioxide is a non-polar solvent, ethanol is used as a co-solvent to increase liquid polarity. The parameters studied were pressure (100, 150, and 200 bar), temperature $\left(40,50\right.$, and $60{ }^{\circ} \mathrm{C}$ ), and dynamic extraction time (40, 60, and 80 minutes). Optimum extraction conditions occur at $200 \mathrm{bar}, 50{ }^{\circ} \mathrm{C}$, and 60 minutes. Based on average values, pressure has a dominant effect on extraction yields. Regardless of the optimal SFE conditions, the other two conditions are the minimum level $\left(100 \mathrm{bar}, 40^{\circ} \mathrm{C}, 40\right.$ minutes) and the maximum (200 bar, $60^{\circ} \mathrm{C}, 80$ minutes $)$ of each parameter studied. At the same time, the control is running analyzed with HPLC to determine the main bioactive flavonoid compounds of S. crispus. Under optimum conditions, eight flavonoid compounds have 


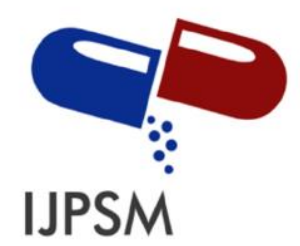

Vika Ramadhani et al, International Journal of Pharmaceutical Sciences and Medicine (IJPSM), Vol.6 Issue. 7, July- 2021, pg. 25-39

ISSN: 2519-9889

Impact Factor: 3.426

been identified; they are (+)-catechin, (-)-epicatechin, rutin, myricetin, luteolin, apigenin, naringenin, and kaempferol [9].

\section{Pharmacological review}

The pharmacological activity of the keji beling has been investigated and summarized in Table 2 below.

Table 2: Pharmacological activity of keji beling plants

\begin{tabular}{|c|c|c|c|c|c|c|c|}
\hline No & $\begin{array}{l}\text { Plant } \\
\text { Parts }\end{array}$ & $\begin{array}{l}\text { Extraction } \\
\text { Methods }\end{array}$ & Solvent & $\begin{array}{l}\text { Active } \\
\text { Compounds }\end{array}$ & Test Method & Activity & Ref. \\
\hline 1. & leaf & Maceration & $\begin{array}{l}\text { Hexane, } \\
\text { Ethyl } \\
\text { Acetate, } \\
\text { Methanol }\end{array}$ & $\begin{array}{l}\text { Terpenoid, } \\
\text { steroid }\end{array}$ & In vitro & Antiurolytic & [7] \\
\hline 2. & leaf & Maceration & $\begin{array}{ll}\text { Ethanol } 96 \\
\%\end{array}$ & - & $\begin{array}{l}\text { In vivo on } \\
\text { mice }\end{array}$ & Antiurolytic & [10] \\
\hline 3. & leaf & Maceration & $\begin{array}{l}\text { Ethyl } \\
\text { Acetate }\end{array}$ & $\begin{array}{l}\text { Monoterpene } \\
\text { D - limonene }\end{array}$ & $\begin{array}{l}\text { Brine Shrimp } \\
\text { Lethality Test } \\
\text { (BSLT) }\end{array}$ & Cytotoxic & [11] \\
\hline 4. & leaf & Maceration & $\begin{array}{l}\text { Water, } \\
\text { ethanol }\end{array}$ & Flavonoid & $\begin{array}{l}\text { 1,1-diphenyl- } \\
1 \text { - } \\
\text { picrylhydrazil } \\
\text { (DPPH) dan } \\
\text { ferric reducing } \\
\text { antioxidant }\end{array}$ & Antioxidant & [12] \\
\hline 5. & leaf & Maceration & ethanol & phenol & DPPH, FRAP & Antioxidant & {$[12]$} \\
\hline 6. & leaf & Maceration & $\begin{array}{l}\text { Methanol, } \\
\text { acetone, } \\
\text { water }\end{array}$ & $\begin{array}{l}\text { Polyphenols, } \\
\text { folic acid, } \\
\text { flavonoids }\end{array}$ & DPPH, FRAP & Antioxidant & [13] \\
\hline 7. & leaf & Maceration & ethanol & $\begin{array}{l}\text { Flavonoids, } \\
\text { alkaloids }\end{array}$ & DPPH & Antioxidant & [14] \\
\hline 8. & leaf & Maceration & ethanol & $\begin{array}{l}\text { Flavonoids, } \\
\text { alkaloids }\end{array}$ & Disc method & $\begin{array}{l}\text { Antibacteri } \\
\text { al }\end{array}$ & [14] \\
\hline 9. & leaf & Maceration & ethanol & $\begin{array}{l}\text { acetic acid, } \\
\text { butyrolactone, } \\
\text { and } \\
\text { hexanedioic } \\
\text { acid }\end{array}$ & Disc method & $\begin{array}{l}\text { Antibacteri } \\
\text { al }\end{array}$ & [15] \\
\hline 10. & leaf & Maceration & $\begin{array}{l}\text { ethanol } \\
70 \%\end{array}$ & $\begin{array}{l}\text { Flavonoid, } \\
\text { Steroid }\end{array}$ & In vitro & $\begin{array}{l}\text { Inhibition } \\
\text { of } \alpha \\
\text { enzymes - } \\
\text { Glucosidase }\end{array}$ & [16] \\
\hline
\end{tabular}




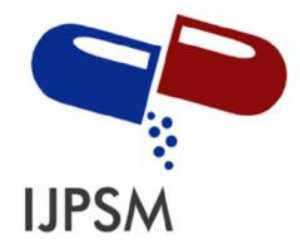

Vika Ramadhani et al, International Journal of Pharmaceutical Sciences and Medicine (IJPSM), Vol.6 Issue. 7, July- 2021, pg. 25-39

ISSN: 2519-9889 Impact Factor: 3.426

\begin{tabular}{|c|c|c|c|c|c|c|c|}
\hline 11. & Leaf Stem & Maceration & methanol & Flavonoid & MTT assay & $\begin{array}{l}\text { Anti- } \\
\text { inflammato } \\
\text { ry }\end{array}$ & $\begin{array}{l}\text { [17] } \\
\end{array}$ \\
\hline 12. & leaf & Maceration & $\begin{array}{l}\text { Chloroform, } \\
\text { methanol }\end{array}$ & Catechins & In vivo & Antiobesity & [18] \\
\hline 13. & leaf & Maceration & ethanol & $\begin{array}{l}\text { Catechins, } \\
\text { Alkaloids, } \\
\text { caffeine, } \\
\text { tannin }\end{array}$ & In vivo & $\begin{array}{l}\text { Wound } \\
\text { healing }\end{array}$ & [19] \\
\hline 14. & $\begin{array}{l}\text { Leaves, } \\
\text { stems }\end{array}$ & $\begin{array}{l}\text { Soxhlet } \\
\text { extraction, } \\
\text { liquid-liquid } \\
\text { partition }\end{array}$ & $\begin{array}{l}\text { Methanol, } \\
\text { ethyl acetate }\end{array}$ & Alkaloid & MTT assay & $\begin{array}{l}\text { CANCER } \\
\text { MCF - 7's } \\
\text { Activity }\end{array}$ & [20] \\
\hline 15. & leaf & Maceration & Diklometana & Lutein & $\mathrm{LDH}$ & $\begin{array}{l}\text { Cancer } \\
\text { cells } \\
\text { MDA-MB- } \\
\text { 231, MCF- } \\
7\end{array}$ & $\begin{array}{l}21] \\
\end{array}$ \\
\hline 16. & $\begin{array}{l}\text { Leaves } \\
\text { and Stems }\end{array}$ & Maceration & $\begin{array}{l}\text { Hexane, } \\
\text { chloroform, } \\
\text { ethyl } \\
\text { acetate, } \\
\text { methanol, } \\
\text { water }\end{array}$ & tannin & MTT assay & $\begin{array}{l}\text { Cancer } \\
\text { Cells } \\
\text { heal }\end{array}$ & [22] \\
\hline 17. & $\begin{array}{l}\text { Leaves } \\
\text { and Stems }\end{array}$ & Maceration & $\begin{array}{l}\text { Ethyl } \\
\text { acetate, } \\
\text { hexane, } \\
\text { chloroform }\end{array}$ & $\begin{array}{l}\text { Alkaloids, } \\
\text { Tannins }\end{array}$ & MTT assay & $\begin{array}{l}\text { Nasopharyn } \\
\text { geal Cancer } \\
\text { CNE-PC }\end{array}$ & [23] \\
\hline 18. & leaf & Maceration & ethanol & $\begin{array}{l}\text { Phenolics, } \\
\text { Flavonoids }\end{array}$ & DPPH & $\begin{array}{l}\text { Colorectal } \\
\text { cancer }\end{array}$ & [24] \\
\hline 19. & leaf & Maceration & $\begin{array}{l}\text { Distilled } \\
\text { water (juice) }\end{array}$ & Polyphenols & MTT assay & $\begin{array}{l}\text { Liver } \\
\text { cancer } \\
\text { Salt HepG2 }\end{array}$ & [25] \\
\hline 20. & leaf & Maceration & ethanol & Flavonoid & MTT assay & $\begin{array}{l}\text { Breast } \\
\text { adenocarcin } \\
\text { oma } \\
\text { MCF-7 }\end{array}$ & [26] \\
\hline 21. & $\begin{array}{l}\text { Leaves } \\
\text { and stems }\end{array}$ & Maceration & $\begin{array}{l}\text { Ethyl } \\
\text { acetate, } \\
\text { methanol }\end{array}$ & Phenolic & MTT assay & $\begin{array}{l}\text { HT-29, } \\
\text { MCF-27. } \\
\text { DU-145, } \\
\text { H460 }\end{array}$ & [27] \\
\hline
\end{tabular}




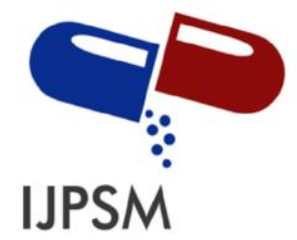

Vika Ramadhani et al, International Journal of Pharmaceutical Sciences and Medicine (IJPSM), Vol.6 Issue. 7, July- 2021, pg. 25-39

ISSN: 2519-9889

Impact Factor: 3.426

\begin{tabular}{|l|l|l|l|l|l|l|l|}
\hline 22. & $\begin{array}{l}\text { Leaves } \\
\text { and Stems }\end{array}$ & Maceration & $\begin{array}{l}\text { Hexane, } \\
\text { Ethyl } \\
\text { Acetate, } \\
\text { Chloroform, } \\
\text { Methanol, } \\
\text { and Water }\end{array}$ & Alkaloid & MTT assay & $\begin{array}{l}\text { Sel HepG-2 } \\
\text { dan MDA- } \\
\text { MB-231 } \\
\text { Liver and } \\
\text { breast } \\
\text { cancer }\end{array}$ & \\
\hline 23. & leaf & Maceration & $\begin{array}{l}\text { Distilled } \\
\text { water (juice) }\end{array}$ & Alkaloid & In vivo & Toxicity & [29] \\
\hline 24. & leaf & filtration & $\begin{array}{l}\text { Ethanol, } \\
\text { distilled } \\
\text { water }\end{array}$ & Flavonoid & In vitro & $\begin{array}{l}\text { Ulcer } \\
\text { Pepticum }\end{array}$ & {$[30]$} \\
\hline
\end{tabular}

\subsection{Antiurolithic}

Traditionally, Strobilanthes crispus was famous for the treatment of kidney disease. The purpose of this study was to validate the traditional use of S. crispus by evaluating its antiurolithic activity in vitro. The titrimetry method was assessed the inhibitory activity of calcium oxalate $(\mathrm{CaOx})$ through aggregation and dissolution tests. The influence of S. crispus and sistone on nucleation and aggregation slope and calcium oxalate crystal growth is evaluated spectrophotometrically. S. crispus is extracted using n-hexane, ethyl acetate, methanol, and water. Methanol $(5.92 \%)$ produced the highest percentage of extracts and showed the most increased inhibitory activity against $\mathrm{CaOx}$ crystal aggregation $(50.54 \pm 2.11 \%)$. Ethyl acetate extract has the most effective dissolution effect against $\mathrm{CaOx}$ crystals $(52.50 \pm 2.50 \%)$. S. crispus significantly $(\mathrm{p}<0.05)$ inhibits the nucleation and aggregation of $\mathrm{CaOx}$ crystals and lowers crystal density. This study validated the traditional use of S. crispus, which was found to exhibit significant antiurolithic activity. However, further research is recommended to isolate and identify active constituents and their in-vivo analysis [7].

Research has been conducted on the influence of ethanol extract of keji beling leaf (Strobilanthes crispus (L) Blume) on the solubility of calcium and oxalate as a component of kidney stones in the urine of white male rats. Kidney stones in experimental animals were induced by using $0.75 \%$ ethylene glycol and $2 \%$ ammonium chloride to form calcium oxalate crystals. The animals in the study were divided into five groups. Group I; negative control, given regular food and water, group II; The positive control group, groups III, IV, and V were induced. The last three groups were given extracts at doses of 100, 200, and $400 \mathrm{mg}$. Treatment is provided for 14 days, and urine is accommodated on the 15th day. Calcium levels in urine are measured using atomic absorption spectrophotometers, while oxalate levels are measured using UV-Vis Spectrophotometers. The results showed that Strobilanthes crispus L Blume leaf extract affects the solubility of calcium and oxalate as a component of kidney stones in the urine. The larger the dose given, the more calcium and oxalate levels dissolved in the urine [10].

\subsection{Cytotoxic}

It has been done isolation and identification of one of the mono-terpenes chemical compounds of the plant Keji beling (local name) (Strobilanthes crispus). Extraction is carried out by maceration of keji beling leaf powder with ethanol 96\%, then partitioned with water-ethyl acetate. Ethyl acetate extract is isolated and purified by cytotoxic guidance fractionation system with Brine Shrimp Lethality Test (BSLT) on column chromatography $(\mathrm{SiO} 2$; n-hexane - ethyl acetate $=20: 1)$. Preparative Thin Layer Chromatography (TLC) $(\mathrm{SiO} 2 ; \mathrm{n}$-hexane ethyl acetate $=10: 1)$ produces one compound in oily form. Based on identification with the infrared spectrum and gas chromatography-mass spectrometry (GC-MS), the compound is a D-Limon monoterpene that has cytotoxic power of $73.11 \mathrm{ppm}[11]$. 


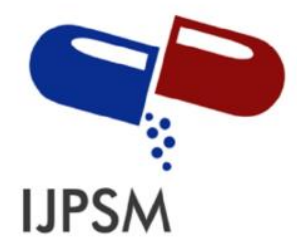

Vika Ramadhani et al, International Journal of Pharmaceutical Sciences and Medicine (IJPSM), Vol.6 Issue. 7, July- 2021, pg. 25-39

ISSN: 2519-9889

Impact Factor: 3.426

\subsection{Antioxidant}

Aqueous extracts and ethanol from various traditional Malaysian plants (Polygonum minus, Andrographis paniculata, Curcuma xanthorrhiza, Momordica charantia, and Strobilanthes crispus) are evaluated for their antioxidant properties, total phenolic content, and cytotoxic activity. Antioxidant activity was assessed using a 1,1-diphenyl-1-picrylhidrazil (DPPH) and ferric reduction antioxidant power test (FRAP). The results showed that ethanol extract contains high antioxidant activity compared to water extract. The findings showed a strong correlation between antioxidant activity and total phenol content. In addition, all plant extracts show a nontoxic effect on regular human lung fibroblast cell lines $(\mathrm{Hs} 888 \mathrm{Lu})$. Although water extracts are traditionally used, we determined that ethanol extracts usually achieve a better activity in testing.

Other studies tested using water, methanol, and acetone extract of keji beling leaves (Strobilanthes crispus Bl.) with concentrations $(25,50,75$, and $100 \%)$ to know the content of phenolics and antioxidants, using the methods of DPPH and FRAP. The results stated that the highest polyphenols and phenolic acids were in $50 \%$ acetone extract, namely 10.80 and $33.86 \mathrm{mg}$ GAW/g DW. In comparison, flavonoids had the highest total of $4.98 \mathrm{mg} \mathrm{QE} / \mathrm{g}$ DW in $100 \%$ acetone extract. DPPH from acetone extract $75 \%$ value of $24.88 \mathrm{mg} \mathrm{TE} / \mathrm{g} \mathrm{DW}$ at the highest antioxidant results, while the highest value FRAP obtained from $25 \%$ acetone extract, namely $47.21 \mathrm{mg}$ TE/g DW. Inferred acetone extract leaves Strobilanthes crispus as the most suitable solvent for phenolic content and antioxidant properties [13].

Keji beling (Strobilanthes crispus B1.) has pharmacological activity as an antioxidant. The antioxidant test was conducted using the DPPH method with vitamin $\mathrm{C}$ as a standard medicine, ethanol extract of keji beling leaves able to ward off free radicals $\mathrm{DPPH}$ with $\mathrm{IC}_{50}, 102.85 \mathrm{ppm}$, and $\mathrm{IC}_{50}$ value of vitamin $\mathrm{C}$ as a comparison solution of $19.268 \mathrm{ppm}$ [14].

\subsection{Antibacterial}

Antibacterial activity of ethanol extract of keji beling leaf (Strobilanthes crispus B1.) was evaluated against bacteria Staphylococcus aureus and Escherichia coli, with the method of disc paper using Ampicillin as a positive control and distilled water as a negative control. Test results of antibacterial activity of ethanol extract keji beling leave in Staphylococcus aureus bacteria with extract concentration of $100 \%$ (5.75 mm) can inhibit the growth of Staphylococcus aureus bacteria and Escherichia coli bacteria [14].

Research conducted by Lim et al. [15] aims to examine the potential antimicrobial activity of Strobilanthes crispus leaf ethanol extract by determining the vulnerability of various microbial strains to extracts and profiles of bioactive compounds in extracts using GC-MS. The antimicrobial activity was assessed using disc diffusion in Aspergillus brasiliensis, Candida albicans, Klebsiella pneumoniae, Pseudomonas aeruginosa, Staphylococcus aureus, and Streptococcus pneumoniae. GC-MS analysis is used to determine the profile of bioactive components of plant parts. The extract showed inhibitory activity against Staphylococcus aureus and Streptococcus pneumoniae at a concentration of $200 \mathrm{mg} / \mathrm{mL}$. At the same time, no inhibition was seen against Aspergillus brasiliensis, Candida albicans, Klebsiella pneumonia, and Pseudomonas aeruginosa. GCMS analysis of ethanol extract reveals several constituents, including acetic acid, butyrolactone, and hexanedioic acid, described in the literature as proven antimicrobial agents. These results suggest that Strobilanthes crispus leaf ethanol extract can be used as a nutraceutical against S. aureus and S. pneumoniae.

\subsection{Antidiabetic}

The keji beling leaf (Sericocalyx crispus (L.) Bremek) [Synonym Strobilanthes crispus (L.)] is one of the plants empirically used by the community to help with treatment. According to research, vile leaves are known to have properties as antidiabetic. This study aims to identify the group of compounds contained in the extract, the quality of the extract, and the inhibitory activity of enzymes $\alpha$-Glucosidase in vitro. The powder is extracted with ethanol solvent $70 \%$ kinetic maceration, then performed phytochemical screening, determination of extract quality, and test of inhibition activity of enzymes $\alpha$-Glucosidase. Screening results showed the extract contained flavonoid compounds, saponins, steroids, and triterpenoids. The results of the 


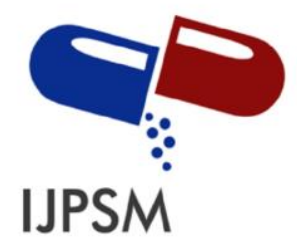

Vika Ramadhani et al, International Journal of Pharmaceutical Sciences and Medicine (IJPSM), Vol.6 Issue. 7, July- 2021, pg. 25-39

determination quality of the extract showed a form of viscous extract in a blackish green color, bitter taste. Water-soluble cider content of $60.46 \%$; soluble ethanol juice content of $73.45 \%$; total ash content of $15.06 \%$; insoluble acid ash content of $3.10 \%$; water-soluble ash content of $11.29 \%$; the moisture content of $7.68 \%$; shrink drying 9,25\%; remaining solvent $0.38 \%$; $\mathrm{Pb}$ rate of $0.4941 \mathrm{ppm}$; Cd rate $0.0222 \mathrm{ppm}$; Total Plate Number (TPC) $4.52 \times 102$ colonies/g; The yeast number is too small to be calculated (TSUD); and total flavonoid content of $2.39 \%$. The inhibitory activity of $\alpha$-Glucosidase enzymes in the root base and thick extracts of keji beling showed IC50 of $50 \mathrm{ppm}$ and $86.2 \mathrm{ppm}$, respectively. It can be concluded that the thick extract of keji beling meets the quality requirements of the extract and has acted as an inhibitor of the enzyme $\alpha$-Glucosidase. Keji beling has the potential to be further developed as an antidiabetic herbal remedy.

\subsection{Anti-inflammatory}

Inflammation is the body's rapid response to dealing with injuries, foreign particles, and damaged cells. Untreated inflammation can lead to complications in the cerebrovascular, cardiovascular system, joints, and intestines. However, conventional drugs available today show adverse effects on many organ systems in addition to treating inflammation. Strobilanthes crispus, a native plant believed to have anti-inflammatory properties, has been used in traditional medicine to treat various diseases. Nevertheless, no scientific research has been conducted to prove this conventional claim. Therefore, this study focused on investigating the antiinflammatory properties of $S$. crispus in an experimental model of lipopolysaccharide-stimulated RAW macrophages (LPS). The maximum non-toxic dose (MNTD) of Methanol extract S. crispus and optimum LPS concentration are determined before determining the anti-inflammatory effect of S. crispus. MNTD S. crispus is determined using the MTT test, and optimum LPS is determined based on nitric oxide production (NO) using Griess reaction. Finally, the anti-inflammatory effect of S. crispus is determined by examining levels of NO and cytokines, namely interleukin-6 (IL-6) and interleukin-10 (IL-10), using the Procarta immunoassay kit. MNTD for S. crispus leaf and stem extract is $160 \mathrm{~g} / \mathrm{mL}$ and $1.5 \mathrm{~g} / \mathrm{mL}$, respectively. The optimum LPS required to induce maximum inflammation is $1 \mathrm{~g} / \mathrm{mL}$. After initial treatment with half MNTD leaf extract (1/2MNTD), no production was significantly reduced, while MNTD stem extract resulted in increased levels of IL-10. On the other hand, no significant decrease in IL-6 production was seen in treatment except indomethacin, which acts as a positive control drug. This study showed that S. crispus could have anti-inflammatory properties in RAW macrophages 264.7 stimulated lipopolysaccharide through suppression of NO production and increased levels of IL-10 [17].

\subsection{Antiobesity}

Strobilanthes crispus leaves are consumed traditionally because of their weight loss effect. In this study, we investigated the antiobesity effects of $S$. crispus leaf extract (SCE). Mice $(\mathrm{n}=48)$ were fed a high-fat diet (HFD) for 25 weeks to induce obesity, after which half were maintained on HFD, and half switched to a lowfat diet (LFD) while they were given ordinary water $\left(\mathrm{H}_{2} \mathrm{O}\right)$ or $0.1 \%(\mathrm{~b} / \mathrm{v})$ of SCE in water at weeks $0-4$ which was increased to $1 \%(\mathrm{~b} / \mathrm{v})$ in weeks 5-9. The treatment with SCE was compared between the $\mathrm{HFDH}_{2} \mathrm{O}$, HFDSCE, $\mathrm{LFDH}_{2} \mathrm{O}$, and LFDSCE groups. The respiratory exchange ratio (RER) is measured in weeks 0,5 , and 10. Food, water intake, and weight are measured weekly. Plasma lipid profile and organ weight are determined in week 10. SCE significantly reduced the RER in week 9 ( $P=0.011)$. Food intake, weight, and weight of abdominal adipose tissue were not altered by SCE at weeks 5 and 10. However, a significant increase in plasma and liver cholesterol $(\mathrm{P}<0,050)$ was also observed. Our findings suggest that SCE induces lipolysis and oxidation of body fat and increases energy expenditure. Further studies on other animal models should be conducted to confirm the consistency of these results [18].

\subsection{Wound healing}

This study was conducted to evaluate the influence of the topical application of Strobilanthes crispus leaf ethanol extract on the speed of wound healing closure and histology of healed wounds. Four groups of 


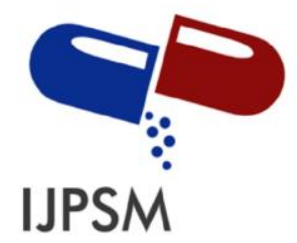

Vika Ramadhani et al, International Journal of Pharmaceutical Sciences and Medicine (IJPSM), Vol.6 Issue. 7, July- 2021, pg. 25-39

ISSN: 2519-9889

Impact Factor: 3.426

Sprague Dawley male rats were all experimentally injured in the posterior neck area. The wound area is uniform with a diameter of $2 \mathrm{~cm}$ using a circular stamp, cut nape of the neck of the back of all mice with the help of a round seal. The animal groups were given topical treatment with $0.2 \mathrm{~mL}$ each vehicle (acacia gum), intrasite gel, 100 and $200 \mathrm{mg} / \mathrm{mL}$ of ethanol extract. Macroscopically, wounds wrapped in leaf extract and groups that were given intrasite gel recovered significantly earlier than those treated by vehicle. Histological analysis of wounds healed with leaf extract showed relatively less wound width at wound closure. It cured wounds containing fewer inflammatory cells and more collagen with angiogenesis compared to vehiclewrapped damages. In conclusion, injuries wrapped in leaf extract significantly improved the acceleration of wound healing in rats, which was confirmed by histological studies.

\subsection{Anticancer activity}

Despite advances in chemical biology and combinatorial chemistry, natural products remain a potential source of development of anticancer drugs today. Strobilanthes crispus (S. crispus) derived from the family Acanthaceae has been used traditionally as a medicine in several countries and is reported to have an anticancer, antioxidant, free radical antidote, antidiabetic, antimicrobial, wound healing, and antiulcerogenic activity. Therefore, the purpose of this study is to find out the antiproliferative properties of S. crispus against breast cancer cells. Chemical compounds are extracted from various parts of the plant using methanol then continued with liquid-liquid partitions. The antiproliferative effects of this extract were tested on MCF-7. Among the extracts, only five showed inhibition of cell proliferation in MCF-7. The best antiproliferative activity was observed in ethyl acetate stem extract and leaf water with IC50 values of $38 \mathrm{~g} / \mathrm{mL}$ and $23 \mathrm{~g} / \mathrm{mL}$, respectively. However, IC50 values for stem chloroform extract, leaf methanol, and leaf chloroform are in the range of 70-90 g/mL. Treatment with S. crispus extract also causes morphological changes in MCF-7 cells. Chromatin condensation and peripheral aggregation of nuclear chromatin are observed in treated cells. However, further investigation is needed to understand the underlying mechanisms [20].

Cancer patients seek alternative treatments such as traditional medicinal plants for safe and effective treatment and help overcome the side effects of conventional therapies. Current knowledge suggests that Strobilanthes crispus extracts from the Acanthaceae family exhibit solid anticancer properties in vitro and are non-toxic in vivo. S. crispus is also reported to be protective against chemical hepatocarcinogenesis. We have previously shown that the bioactive fraction of $S$. crispus leaves also synergizes with tamoxifen to cause apoptosis of human breast cancer cells without damaging non-malignant epithelial cells. This study aimed to evaluate the antitumor effect of $S$. crispus (F3) dichloromethane fraction using a mouse mammae tumor model induced N-methyl-N-Nitrosourea (NMU). Tumor regression was observed in $75 \%$ of rats after eight weeks of oral administration of $\mathrm{F} 3$ without the formation of secondary tumors and no signs of anemia or infection. However, no improvement in liver and kidney function profiles was observed. The main constituents of F3 are lutein, 131-hydroxy-132-oxo-pheophytin campesterol, stigmasterol, $\beta$-sitosterol, pheophytin a, and 132hydroxy-pheophytin a. However, this compound may not significantly contribute to the antitumor effect of F3 [21].

Strobilanthes crispus extract was found to provide cytotoxicity in some cancer cell lines and reduce chemically induced hepatocarcinogenesis in mice. In this study, the cytotoxicity of S. crispus extract isolated from leaves and stems with hexane, chloroform, ethyl acetate, methanol, and water solvents was determined, and the possible underlying mechanisms of apoptosis were investigated further in HeLa cell lines. MTT analysis showed that only hexane stem extract showed cytotoxic effects on HeLa cells with IC50 $160 \mathrm{~g} / \mathrm{mL}$. Chloroform extract shows a tendency to inhibit cells, while other extracts show little or no cytotoxic effect. Hexane stem extract was further analyzed in this study. It was found to induce apoptosis, which was confirmed by apparent morphological changes in HeLa cells accompanied by the detection of sub-G1 peaks in cell cycle analysis with flow cytometry. Hexane stem extract does not induce cell cycle termination at any phase based on the data shown. Detected caspase-3/7 activity indicates involvement of caspase-3/7 activation in apoptogenic effects induced by hexane stem extract. The activity of caspase- 8 and caspase- 9 was found to be insignificant in this study. More research can be done to explain the mechanism of apoptosis better clearly. The 


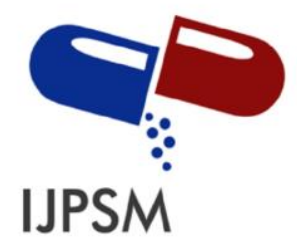

Vika Ramadhani et al, International Journal of Pharmaceutical Sciences and Medicine (IJPSM), Vol.6 Issue. 7, July- 2021, pg. 25-39

ISSN: 2519-9889

Impact Factor: 3.426

overall findings suggest that $S$. crispus acts as an apoptosis induction that can be used as a potential anticancer agent in the future [22].

Chemotherapy agents used to treat nasopharyngeal cancer (NPCs) show low efficacy. Strobilanthes crispus Blume is widely used for its anticancer, diuretic, and antidiabetic properties. This study aims to determine the cytotoxic and apoptogenic effects of $S$. crispus on CNE-1 NPC cells. Test 3-(4,5-dimethylthiazol-2-yl)-2,5 diphenyl tetrazolium bromide was used to evaluate the cytotoxic effect of S. crispa on CNE-1 cells. The level of apoptosis is determined using propidium iodide staining and caspase test. Extracts of ethyl acetate, hexane, and chloroform of S. crispus leaves all show cytotoxic effects on CNE-1 cells, at half-maximum inhibitory concentrations (IC50) of 119, 123.5, and $161.7 \mathrm{~g} / \mathrm{mL}$, respectively. In addition, hexane, chloroform, and ethyl acetate extracts from the stem of $S$. crispus inhibit the proliferation of CNE-1 cells, an IC50 of 49.4, 148.3, and $163.5 \mathrm{~g} / \mathrm{mL}$, respectively. Cytometric flow analysis revealed an increase in the proportion of cells in the sub-G1 phase and decreased the proportion of cells in the G2/M phase after treatment with extracts. However, the extract does not change the activity of caspase $-3 / 7,8$, and 9 . No cytotoxic effect is observed when cells are treated with methanol and water extract from the stems and leaves of $S$. crispus. In conclusion, S. crispus extract is cytotoxic to CNE-1 cells, and this extract can induce apoptosis, regardless of caspase activation [23]. In this study, microscopic and histological studies showed that Strobilanthes crispus ethanol extract reduced azoxymethane (AOM)-induced colonic aberrant crypt foci (ACF) in rats. S. crispus is considered a folk remedy and is used as an antioxidant. Its leaves contain many phenolic compounds that act as radical catchers and enhance their ability to eradicate oxidative stress reactions. This study was designed to determine the chemopreventive effects of S. crispus in vivo and in vitro ethanol extract by explaining the impact of the extract on intermediate biomarkers that can be used as effective predictors of colon cancer. S. crispus was analyzed for free radical DPPH, nitric oxide (NO), and iron acid reduction. The results showed that oral administration of $S$. crispus significantly inhibited colorectal carcinogenesis induced by AOM, as indicated by a decrease in the amount of ACF. S. crispus lowers the regulation of expression of PCNA, Bcl2, and $\beta$ catenin. In addition, it provides a noticeable inhibitory effect on MDA and NO levels and a stimulatory effect on the activity of CAT and GPx. These results suggest that $S$. crispus is a chemopreventive agent for colorectal cancer through suppression of early and intermediate carcinogenic phases that may be associated with its flavonoid content [24].

Hepatocellular carcinoma is one of the most common cancers in the world. Its prevalence is increasing in many countries. Plant products can be used to protect against cancer due to their natural anticancer and chemopreventive constituents. Strobilanthes crispus is one of the plants that have the potential to have chemopreventive abilities. This study aims to evaluate the anticancer effect of Strobilanthes crispus juice on hepatocellular carcinoma cells. MTT tests, flow cytometry, comet tests, and reverse transcription-polymerase chain reaction (RT-PCR) are used to determine the effect of juice on DNA damage and the number of cancer cells. This juice induces apoptosis after exposure to HepG2 cell lines for 72 hours. The percentage of apoptosis cell death and significant DNA damage was seen in juice concentrations above $0.1 \%$. It was found that the juice was not toxic to normal cells. In addition, exposure to fluid increases the level of expression of the c-myc gene and reduces the level of expression of the c-fos and c-erbB2 genes in HepG2 cells. The cytotoxic effect of juice on abnormal cells depends on the dosage. It was concluded that Strobilanthes crispus juice might have a chemopreventive effect on hepatocellular carcinoma cells [25].

Strobilanthes crispus is traditionally used as an antidiabetic, anticancer, diuretic, antilithic, and laxative agent. However, the cytotoxicity and antiproliferative effects of S. crispus are still unclear. Strobilanthes cripus was able to reduce cell viability and proliferation in MTT and BrdU tests. Cell cycle progression and Tunel tests show that IC50 S. crispus ethanol extract induces sub-G1 cell cycle phases and DNA fragmentation. On the other hand, translocation of mitochondrial cytochrome c release, induction of caspase 3/7 and p53 while suppressing XIAP in treated MCF-7 cells was also observed in this study. Our findings suggest that $S$. crispus ethanol extract induces apoptosis and DNA fragmentation in breast cancer cell pathways that depend on the hormone MCF-7 through the mitochondrial-dependent p53 apoptosis pathway [26]. 


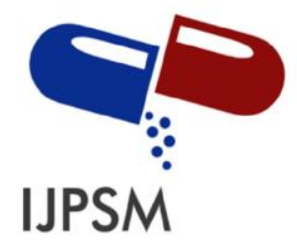

Vika Ramadhani et al, International Journal of Pharmaceutical Sciences and Medicine (IJPSM), Vol.6 Issue. 7, July- 2021, pg. 25-39

ISSN: 2519-9889

Impact Factor: 3.426

Different parts of the four edible medicinal plants (Casearia capitellata, Baccaurea motleyana, Phyllanthus pulcher, and Strobilanthes crispus), native to Malaysia, are extracted in different solvents, sequentially. Twenty-eight extracts obtained were evaluated for their in vitro anticancer properties, using MTS tests, on four lines of human cancer cells: colon (HT-29), breast (MCF-7), prostate (DU-145), and lung (H460) cancer. The best anticancer activity observed for ethyl acetate extract (EA) leaves Casearia capitellata on MCF-7 cell strains with IC50 $2.0 \mathrm{~g} / \mathrm{mL}$ and methanol extract $(\mathrm{MeOH})$ shows remarkable activity against lung cancer cells. The dichloromethane extract (DCM) air part of the Phyllanthus pulcher showed the highest anticancer activity against the DU-145 cell line. In contrast, significant activity was demonstrated by the Phyllanthus pulcher root DCM extract in colon cancer cells with an IC50 value of $8.1 \mathrm{~g} / \mathrm{mL}$. The total phenolic content (TPC) ranges from more than 1-40 mg to the equivalent of error acid (GAE)/g. For all samples, the highest phenolic results were obtained for $\mathrm{MeOH}$ extract. Among all the extracts analyzed, the $\mathrm{MeOH}$ extract of Strobilanthes crispus leaf showed the highest TPC compared to other samples $(\mathrm{p}<0.05)$. This study indicates that phenol properties determine their anticancer activity and not the number of phenols present [27].

Cancer is a significant public health problem not only in developed countries but also in developing countries. It is one of the leading causes of death worldwide. However, current treatments can cause severe and dangerous side effects. Therefore, recent research has focused on identifying alternative therapeutic agents extracted from plant-based sources to develop new treatment options for cancer. Strobilanthes crispa Blume is a plant native to countries including Madagascar and Indonesia. It has been used as an antidiabetic, diuretic, and laxative in traditional medicine.

Furthermore, S. crispus has potential in treating cancer, as evidenced in previous research. In this study, cytotoxic activity and apoptosis of crude extracts of $S$. crispus were investigated on liver and breast cancer cell lines. Extracts of hexane, ethyl acetate, chloroform, methanol, and water made from leaves and stems of $S$. crispus were evaluated for cytotoxicity in HepG-2 and MDA-MB-231 cells the MTT test. The antiproliferative properties of hexane stem extract $(\mathrm{SH})$ in both cell lines were analyzed using cell doubling timing and cell cycle analysis, while apoptogenic properties were determined through caspase- 8 detection. Among the extracts tested, SH extracts showed the lowest half-maximum inhibitory concentration in both cell lines. SH extract induces morphological changes in HepG-2 and MDA-MB-231 cells and significantly delays the doubling time of cell populations. Additionally, it changes the cell cycle profile and significantly increases the activity of caspase-8 in HepG-2 cells but not in MDA-MB-231 cells. In conclusion, SH extract from S. crispus has potent anticancer properties and can be the target of appropriate chemotherapy [28].

\subsection{Anti-ulcerogenic}

The anti-ulcerogenic activity of Strobianthes crispus leaf extract was evaluated against ethanol-induced mucosal injury in rats. Five groups of Sprague Dawley mice were given initial treatment each with: vehicle, distilled water (ulcer control), omeprazole (20mg/kg, reference control), $250 \mathrm{mg} / \mathrm{kg}, 500 \mathrm{mg} / \mathrm{kg}$, and 1000 $\mathrm{mg} / \mathrm{kg}$ of $S$. crispus leaf extract (experimental group), 60 minutes before oral administration of absolute ethanol to produce gastric mucosal injury. Sixty minutes later, the rats were sacrificed, and gastric contents, mucus, and walls were collected. In general, ulcer control mice showed severe injury to the gastric mucosa. They decreased the $\mathrm{pH}$ of gastric mucus content. At the same time, mice treated with $S$. crispus leaf extract resulted in a significant reduction in the formation of dose-dependent gastric lesions accompanied by a substantial increase in the stomach. Mucous production and $\mathrm{pH}$ of gastric fluid. Gastric protection is more prominent in the $1000 \mathrm{mg} / \mathrm{kg}$ treatment group S. crispus. Histology ulcer control mice showed the most severe and most bottomless necrotic damage to the gastric mucosa, with edema and leukocyte infiltration in the submucosal layer compared to experimental and reference control groups. Thus, our data suggest that the protective activity of $S$. crispus ulcer may be due to defensive mucin secretion and increased $\mathrm{pH}$ of gastric contents, and fewer mucosal injuries, no edema, and infiltration of leukocytes in the submucosal. Furthermore, acute toxicity studies have shown no death at a dose of $5 \mathrm{~g} / \mathrm{kg}$ of S. crispus in Sprague Dawley and produced no significant clinical signs of toxicity [30]. 


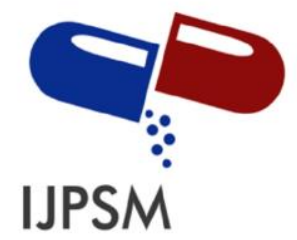

Vika Ramadhani et al, International Journal of Pharmaceutical Sciences and Medicine (IJPSM), Vol.6 Issue. 7, July- 2021, pg. 25-39

ISSN: 2519-9889

Impact Factor: 3.426

\section{Toxicity}

The study evaluated four different doses of Strobilanthes crispus juice $(700,2100,3500$, and $4900 \mathrm{mg} / \mathrm{kg}$ body weight) administered orally in female and male Sprague Dawley mice to possible changes in various physical, behavioral, morphological, and biochemical parameters. The mice were given a single dose of squeezing and observed for 14 days. No significant toxicity was observed in connection with the clinical parameters and morphology of the organ. In addition, no significant changes were observed at levels of aspartate aminotransferase, alanine aminotransferase, alkaline phosphatase, creatinine, and albumin. S. crispus juice was found safe at the maximum dose used in this study (4900 mg/kg body weight) [29].

\section{Conclusion}

Keji beling plant (Strobilanthes crispus B1.) is one of the plants that can be used for folk remedies rich in chemical compounds scattered on each part of the stem and its leaves. The chemical compound is flavonoids, saponins, steroids, triterpenoids, alkaloids, terpenoids, tannins, carbohydrates, phytosterols, and phenolic. Keji beling plant has various pharmacological effects that have antiurolithic effects, antidiabetic, antioxidant, antibacterial, anti-inflammatory, antiobesity, wound healing, anticancer, cytotoxic, and peptic ulcer. Keji beling can be categorized as plants that are safe to eat.

\section{References}

[1]. Cheong BE, Zakaria NA, Cheng AY, Teoh PL. GC-MS Analysis of Strobilanthes crispus plants and callus. Transactions on Science and Technology. 2016 Jun 30;3(1-2):155-161.

[2]. Nurraihana H, Norfarizan-Hanoon NA. Phytochemistry, pharmacology and toxicology properties of Strobilanthes crispus. International Food Research Journal. 2013 Sep 1;20(5):2045-2056.

[3]. http://hukor.kemkes.go.id/uploads/produk hukum/KMK No. HK .01 .07-MENKES-1872017_ttg_Formularium_Ramuan_Obat_Tradisional_Indonesia_pdf

[4]. https://www.academia.edu/28730934/Acuan_Sediaan_Herbal_Volume_2_Edisi_Pertama

[5]. https://www.scribd.com/document/187199718/Inventaris-Tanaman-Obat-Indonesia-I-Jilid-1

[6]. https://www.scribd.com/document/290440577/Atlas-Tumbuhan-Obat-Indonesia-Jilid-4

[7]. Gul MT, Dheyab AS, Shaker EK, Muhammad N, Pauzi AN. In vitro evaluation of anti-urolithiasis properties of Strobilanthes crispus extracted using different solvents. Research Journal of Chemistry and Environment_Vol. 2020 Jan; 24:1

[8]. Fernandes MC, Krishnan S. Phytochemical analysis of Strobilanthes Blume species from Northern Western Ghats of India.2016:118-111

[9]. Liza, M.S., Abdul Rahman, R., Mandana, B., Jinap, S., Rahmat, A., Zaidul, I. S. M. and Hamid, A. 2010. Supercritical Carbon Dioxide Extraction of Bioactive Flavonoid from Strobilanthes crispus (Pecah Kaca). Food and Bioproducts Processing 88: 319 - 326.

[10]. Dharma S, Aria M, Syukri EF. Effect of ethanol extract of kejibeling leaves (Strobilanthes crispa (L) Blume) on the solubility of calcium and oxalate as a component of kidney stones in the urine of white male rats. SCIENTIA: Journal of Pharmacy and Health. 2016 Oct 14;4(1):34-37.

[11]. Sulastri L, Lestari MR, Simanjuntak P. Isolation And Identification of Monoterpene Chemical Compounds From The Fraction of Etilasetat Leaves Keji Beling (Strobilanthes crispa (L.) Blume) Which Has Cytotoxic Power. Fitofarmaka Indonesia Journal, 2021; 8(1) 12-17

[12]. Suhailah, W. Q., Mahmood, A. A., Lee, S. C., Nigar, N., Mazatulikhma, M. Z. and Salehhuddin, H. 2011. Antioxidant, total phenolic content, and cytotoxicity evaluation of selected Malaysian plants. Molecules 16: 3433 3443.

[13]. Haida Z, Nakasha JJ, Hakiman M. Phenolics content and antioxidant properties of Strobilanthes crispus as affected by different extraction solvents. Fundamental and Applied Agriculture Vol. 5(4), pp. 584-589: 2020

[14]. Adibi1 S, Nordan H, Ningsih NS, Kurnia M, Evando, Rohiat S. Antioxidant and Antibacterial Activity of Estrak Leaves of Strobilanthes crispus Bl (Keji Beling)) against Staphylococcus aureus AND Escherichia coli. Journal of Education and Chemical Sciences. 2017: 1(2): 148-154. 


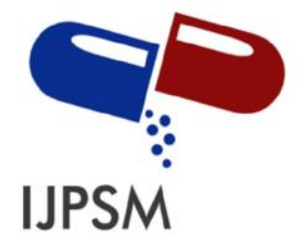

\section{Vika Ramadhani et al, International Journal of Pharmaceutical Sciences and Medicine (IJPSM), Vol.6 Issue. 7, July- 2021, pg. 25-39}

[15]. Lim V, Yap CS, Chong HW, Shukkoor MS, Priya M. Antimicrobial evaluation and GC-MS analysis of Strobilanthes crispus ethanolic leaf extract. European Journal of Medicinal Plants. 2015 Sep 12:1-8.

[16]. http://jamu.journal.ipb.ac.id/index.php/JJI/article/view/181

[17]. Wong YP, Jeya Seela A, Rao PA, Ling AP, Koh RY. Anti-inflammatory Effect of Strobilanthes crispus methanolic extract on Lipopolysaccharide-stimulated RAW 264.7 Macrophages.

[18]. Zawawi N, Ismail M. Strobilanthes crispus extract reduces respiratory exchange ratio in obese mice fed high fat and low-fat diets. The Malaysian journal of medical sciences: MJMS. 2018 Nov;25(6):46-58

[19]. Al-Henhena N, Mahmood AA, Al-Magrami A, Syuhada AN, Zahra AA, Summaya MD, Suzi MS, Salmah I. Histological study of wound healing potential by ethanol leaf extract of Strobilanthes crispus in rats. Journal of Medicinal Plants Research. 2011 Aug 18;5(16):3660-3666.

[20]. Gordani N, Cheong BE, Teoh PL. Antiproliferative Effect of Strobilanthes crispus on MCF-7 Cell Line. Transactions on Science and Technology. 2017 Nov 28;4(3-3):414-419.

[21]. Yaacob NS, Yankuzo HM, Devaraj S, Wong JK, Lai CS. Antitumor action, clinical biochemistry profile, and phytochemical constituents of a pharmacologically active fraction of S. crispus in NMU-induced rat mammary tumor model. PloS one. 2015 May 22;10(5):e0126426.

[22]. Chong YH, Koh RY, Ling AP, Chye SM, Yew MY. Strobilanthes crispus extract induces apoptosis through enhanced caspases activities in cervical cancer cells. In International Conference on Biological, Environment and Food Engineering (BEFE-2014) August 2014 (pp. 4-5).

[23]. Koh RY, Sim YC, Toh HJ, Liam LK, Ong RS, Yew MY, Tiong YL, Ling AP, Chye SM, Ng KY. Cytotoxic and apoptogenic effects of Strobilanthes crispa Blume extracts on nasopharyngeal cancer cells. Molecular medicine reports. 2015 Oct 1;12(4):6293-6299.

[24]. Al-Henhena N, Khalifa SA, Ying RP, Hassandarvish P, Rouhollahi E, Al-Wajeeh NS, Ali HM, Abdulla MA, ElSeedi HR. Chemopreventive effects of Strobilanthes crispus leaf extract on azoxymethane-induced aberrant crypt foci in rat colon. Scientific reports. 2015 Aug 26;5(1):1-13.

[25]. Hussin F, Eshkoor SA, Rahmat A, Othman F, Akim A, Eshak Z. Strobilanthes crispus juice concentrations and anticancer effects on DNA damage, apoptosis and gene expression in hepatocellular carcinoma cells. Asian Pacific Journal of Cancer Prevention. 2015;16(14):6047-6053.

[26]. Chong HZ, Rahmat A, Yeap SK, Akim AM, Alitheen NB, Othman F, Gwendoline-Ee CL. In vitro cytotoxicity of Strobilanthes crispus ethanol extract on hormone-dependent human breast adenocarcinoma MCF-7 cell. BMC complementary and alternative medicine. 2012 Dec;12(1):1-10

[27]. Maznah, I., Bagalkotkar, G., Shahid, I. and Hadiza, A. A. 2012. Anticancer Properties and Phenolic Contents of Sequentially Prepared Extracts from Different Parts of Selected Medicinal Plants Indigenous to Malaysia. Molecules 17: 5745 - 5756.

[28]. Koh RY, Lim FP, Ling LS, Ng CP, Liew SF, Yew MY, Tiong YL, Ling AP, Chye SM, Ng KY. Anticancer mechanisms of Strobilanthes crispa Blume hexane extract on liver and breast cancer cell lines. Oncology letters. 2017 Oct 1;14(4):4957-4964.

[29]. Norfarizan-Hanoon NA, Asmah R, Rokiah MY, Fauziah O, Faridah H. Absence of Toxicity of Strobilanthes crispa Juice in Acute Oral Toxicity Study in Sprague Dawley Rats (Ketiadaan Ketoksikan Jus Strobilanthes crispa Bagi Ketoksikan Akut Secara Oral Pada Tikus Sprague Dawley). Sains Malaysiana. 2012;41(4):403-409.

[30]. Mahmood A, Fard AA, Harita H, Amin ZA, Salmah I. Evaluation of gastroprotective effects of Strobianthes crispus leaf extract on ethanol-induced gastric mucosal injury in rats. Scientific Research and Essays. 2011 Jun 4;6(11):23062314. 


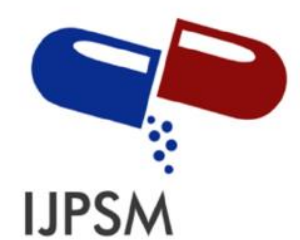

Vika Ramadhani et al, International Journal of Pharmaceutical Sciences and Medicine (IJPSM),

Vol.6 Issue. 7, July- 2021, pg. 25-39

ISSN: 2519-9889

Impact Factor: 3.426

\section{A Brief Author Biography}

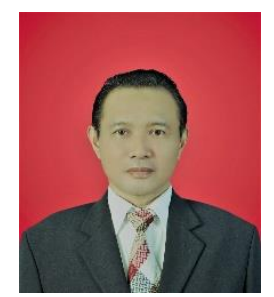

Prof. Dr. Harrizul Rivai, M.S. was born in Payakumbuh, West Sumatra, on 4 September 1953. His father is Rivai Said, and his mother is Saridahanum Syofyan. The Author obtained a Bachelor of Pharmacy from the Department of Pharmacy, Faculty of Mathematics and Natural Sciences, Padjajaran University, Bandung (1976), a Master of Science degree from the Bandung Institute of Technology (1984), and a Doctorate from the Department of Chemistry, Faculty of Mathematics and Natural Sciences, Andalas University, Padang (2011). Now the Author is a Professor and Researcher at the Faculty of Pharmacy, Andalas University, Padang. The Author also serves as Deputy Chair of Academic Affairs at the YPTIK Padang College of Pharmacy (STIFARM). The Author wrote the book "Principles of Chemical Examination" (Publisher UI-Press, 1995), translated the book "Pharmaceutical Statistics" (EGC Medical Book Publishers, 2010), and wrote "Chapter 4 " in the book "Recent Research Advances in Biology Vol. 4" (Book Publisher International, India, and United Kingdom, 2020), and wrote the book "Chinese Petai (Leucaena leucocephala): Traditional Uses, Phytochemicals, and Pharmacological Activities" (Deepublish, Yogyakarta, 2021). He wrote "Chapter 9" in the book "Recent Research Advances in Biology Vol. 7" and "Chapters 5, 6, 7, and 8" in the book "Technological Innovation in Pharmaceutical Research Vol. 3 (Book Publisher International, India, and United Kingdom, 2021). The Author has also written articles in various international journals in various science fields, such as chemistry, biology, and pharmacy. 